\title{
Situations that Make Students Happy and Unhappy in Schools
}

\author{
Süleyman Göksoy \\ Faculty of Education, Duzce University, Turkey
}

Copyright $\bigcirc 2017$ by authors, all rights reserved. Authors agree that this article remains permanently open access under the terms of the Creative Commons Attribution License 4.0 International License

\begin{abstract}
Many research carried out so far have demonstrated that there is a direct relationship between individuals' happiness and aspects of their behaviours. That is to say, happiness has a positive relationship with life quality, job satisfaction, aggression, self-efficacy levels of individuals, vitality, optimism, altruism (self-sacrifice for the welfare of others without benefit), authenticity and self-compassion. According to the results of the research carried out by Senturk (2011), it was observed that the level of happiness may change in terms of socio-demographic features; however it provides similar results fundamentally. In his research, Sarici (2016) established that the level of happiness in the family has a positive meaningful impact on the examination results of secondary school education. In a research conducted with university students, no meaningful difference among the happiness, optimism and altruism levels of students was observed in terms of gender variable. However, the same research demonstrated that there was a meaningful difference among the happiness, optimism and altruism levels of students in terms of faculty variable. The aim of the present research is to determine the educational situations that make student teachers happy and unhappy throughout their educational lives. In line

interpreted. Opinions of the participants were cited without any change. Identities of the participants were kept private and pseudonyms for the students were used in each interview form in data analysis. Research process and operations were tried to be explained in detail in order to increase the transmissibility of the research. All of the findings were provided in order to increase the internal consistency. Study Group; Maximum variation sampling techniques from purposeful sampling method were used in determining the study group of the research. The study group consists of 178 students who study in various sections of faculty of education in Duzce province in 2016-2017 academic year. Also, the students participated in the research voluntarily. Results; since the educational system is based on examinations and grades, students become happy when they get higher grades and they become unhappy for low grades. In secondary education, what makes students happy the most is the presence and quality of social relationship, as a result of social and emotional development. It was observed that university students become happier when they experience positive behaviours and attitudes for their interests, values and respects.
\end{abstract} with this aim, the following questions were studied: What are the school experiences-memories that make students happy? What are the school experiences-memories that make students unhappy? What should be increased and provided more in schools? Research Model? Case study method from qualitative research methods was used in the research. Case study enables deliberate examination of the research subject. It is a favoured method in understanding various topics of education, especially when the questions of 'what, how, why' are posed in the present research, the case is educational experiences and memories that make students happy and unhappy throughout their educational lives. Data Collection, Analysis and Interpretation; In the research, interviewing method was used in data collection. The data were analysed with content analysis techniques and were presented regarding the questions posed in interview processes. Accordingly, similar data were gathered within certain concepts. They were organized and
Keywords Happiness, School Experience, Situations,

\section{Problem Status}

Farabi who was called Second Teacher after Aristo due to his deep knowledge and perspective in philosophy and various sciences suggested that the aim of education is to find happiness (Akyuz, 2015). As Apple (2017) mentioned, children spend most of their lives in school buildings. They grasp authority relationships by endeavouring emotionally in order to demonstrate their personalities and cooperate with other people with whom they share similarities and differences. Alternations in this key organization, various inclinations that we may or may not choose various values, Qualitative Research 
interests, affection and cooperation are the main blocks of personal identity. Also the absence of these factors has great impact on personal development.

Traditional (Classical) education regarded individual as a rational creature which is made of intelligence and followed a cognitive disciplinary approach. It shaped the educational activities within the scope of this understanding. However, handles individual as a whole. It targets cognitive, physical, social and emotional developments at the same time. Evaluations which are mainly based on cognitive skills of students causes exclusions of unsuccessful students in school. Therefore, emotional experiences and social relationships of the students should be considered (Gunduz, 2012). Research demonstrates that any decrease in emotions makes an important reason for irrational behaviour. Emotions facilitate cognitive performance as long as they are directed constructively. Emotions are the internal source of energy, activity and information. They are neither good nor bad. (Cooper, Sawaf, 2010).

Happiness is one of the most important emotions which form the affective domain of humans. Acikalin (2000) indicates that happiness may be the emotion that the world is deprived of the most. This emotion is a relative one and it may depend on individuals, however the main desire of people in life is to be happy. Happiness means that people live in an environment that is convenient for their basic values. The more the life, environment, daily life routines and conditions of a person are coherent to his basic values, the more he is happy and satisfied with life. Aydin, A. (2016) asks what happiness means in his work named "Happiness". He states that parents who manage to teach their children how to have a happy and honorable life are successful parents. He adds that happiness generates new happy situations and success leads to more success.

Many research carried out so far have demonstrated that there is a direct relationship between individuals' happiness and aspects of their behaviours. That is to say, happiness has a positive relationship with life quality, job satisfaction, aggression, self-efficacy levels of individuals, vitality, optimism, altruism (self-sacrifice for the welfare of others without benefit), authenticity and self-compassion. (Cakiroglu, 2007; Kara, 2010; Yalcin, 2016; Sarici, 2016; Duran, 2016; Yazici, 2015; Sahin, 2015; Duman, 2014). According to the results of the research carried out by Senturk (2011), it was observed that the level of happiness may change in terms of socio-demographic features, however it provides similar results fundamentally. In his research, Sarici (2016) established that the level of happiness in the family has a positive meaningful impact on the examination results of secondary school education. In a research conducted with university students, no meaningful difference among the happiness, optimism and altruism levels of students was observed in terms of gender variable. However, the same research demonstrated that there was a meaningful difference among the happiness, optimism and altruism levels of students in terms of faculty variable. (Sahin, 2015). The aim of the present research is to determine the educational situations that make student teachers happy and unhappy throughout their educational lives. In line with this aim, the following questions were studied:

1. What are the school experiences-situations that make students happy?

2. What are the school experiences-situations that make students unhappy?

3. What should be increased and provided more in schools?

\section{Research Model}

Phenomenologic method from qualitative research methods was conducted in the research. Phenomenology is the conscious experience of their life-worlds of people (Schram, 2013, cited from Merriam, 2013). In phenomenology, it is aimed to reveal experiences and meanings related to phonemena. Data sources of phenomenologic research are individuals and groups that experience the related phenomenon and that can reflect it (Yildirim and Simsek, 2008). The present phenomenologic research aimed to reveal the educational experiences and situations that make students happy and unhappy throughout their educational lives and to determine how they interpret and react to these experiences. Therefore, the attitudes of the students towards their educational experiences that made them happy and unhappy were analyzed in detail and a holistic meaning was desired to achieve.

\section{Data Collection, Analysis and Interpretation}

The research data were collected with interview method within the scope of survey research. Surveying is the most preferred data collection technique in social sciences and related applied fields. Surveys are suitable for research questions asking the beliefs and behaviors of the individuals (Neuman, 2014). In the research, interviewing method was used in data collection. The data were analysed with content analysis techniques and were presented regarding the questions posed in interview processes. Accordingly, similar data were gathered within certain concepts. They were organized and interpreted. Opinions of the participants were cited without any change. Identities of the participants were kept private and pseudonyms for the students were used in each interview form in data analysis. Research process and operations were tried to be explained in detail in order to increase the transmissibility of the research. All of the findings were provided in order to increase the internal consistency. 


\section{Study Group}

Maximum variation sampling techniques from purposeful sampling method were used in determining the study group of the research. Purposeful sampling enables profound study of the situations which involve rich content (Yildirim and Simsek, 2008). The study group consists of 178 students who study in various sections of faculty of education in Duzce province in 2016-2017 academic year. The students participated in the research voluntarily. 24 students are from Turkish, 29 students are English, 63 students are Psychological Counseling and Guidance, 45 of them are classroom and 17 of them are Science teaching students.

\section{Findings}

\section{a) School experiences-situations that make students happy}

School experiences-situations that have made student teachers who studies in Faculty of Education happy throughout their educational lives are;

(a) Participation to classroom-school activities, participation to lesson $(n=70)$

(b) Appreciation - rewarding $(\mathrm{n}=65)$

(c) Success $(\mathrm{n}=60)$

(d) Social relationships $(\mathrm{n}=74)$

Direct opinions of the participants related to these factors are given below.

a) Participation to Classroom-school Activities, Participation to Lesson

Ayșe, "I became happy when I successfully submitted my homework or I got high scores in exams", Hatice, "I read poems on April 23 National Sovereignty and Children's Day and on Republic Day, attended activities, became a presenter and all of these made me happy", Veli, "I was accepted to the athletics team", Kağan "In primary school, intramural social activities made me very happy. I always attended sportive activities. Once there was a Caucasian show and being part of the show made me really happy. What have made me happy the most is passing the aptitude test with first rank", Mert, "I was really happy when we were successful as the school team", Mehmet, "Our high school trips were really fun", Olcay, "Courses that I had the chance to participate to made me happy. My English and Literature teachers always pointed me as a model", Selma, "The teacher chose me as the class president. I was very proud and I treated my friends very strictly", Mert, "We played basketball in a tournament with other classes in 5th grade. I was very happy when we became champion and when I raised the cup", Deniz, "In primary school, our teacher taught us how to cook tarhana soup and we drank it together", Melisa, "We decorated the classroom on a birthday of one of our classmates, we had fun", Zühre, "I clearly remember the day when I started school and I was very happy. I got prepared for April 23 National Sovereignity and Children's Day and I presented in front of my family. Also the excitement of being able to read the writings on newspaper and TV made my very happy".

b) Appreciation - Rewarding

Asl1, "Our teacher gave certificate of appreciation and a book to the most successful students in the class", Leyla, "I got happy when I answered the question on the board. Also I got appreciated in school shows and dramas", Alp, "I got appreciated for my well-prepared homework", Dilek, "In high school, I was indecisive for maintaining my education due to some health problems. I drew for a painting contest. I drew Halic which starts from Eyub Sultan. I became first in Eyup with that painting. The mayor presented my reward in front of my family and other participants. This was not just a reward, it was my motivation to maintain my education. Then I graduated high school in second place", Ziya "Things that made me happy were dinner times in kindergarten, red ribbon that I got for learning how to read faster than my classmates, appreciation certificate that was given to me in 7th grade, mathematics lessons in secondary school, a professor in university who wanted to see me in lessons."

c) Success

Ali, "Being a successful student, I was appreciated by my teachers and family and it made me happy", Veli "I was really happy when I passed Anatomy lesson ", Hasan "I was second most successful student in 6th grade, we had championship in school football team in 8 th grade and I was in 3 rd rank in an essay contest in 7 th grade", Mualla, "I became happy when I was successful in lessons and when I was appreciated for the products that I produced or designed", Irem, "I was happy when I was successful in the classroom and when I got high scores ", Ezgi, "It was a report card day in 5th grade, my teacher loved me very much and I was the most successful student in the classroom. Only on my report card was an evil eye talisman. She said that she was sure that I would be successful in the future as well", Sadet, "In the second year of high school, I was very successful in the examination of the course and I had the chance to go to the course free", Derya, "In primary school, the teacher asked how many parliamentarians there are in TBMM and only I said the correct answer. The whole class gave an applause to me.".

d) Social Relationships

Özge "I was happy when I spent time with my friends", Alp, "Having friends in school and spending time with them made me happy", Han, "What made me happy the 
most in school was the healthy communication I had with my friends and teachers", Ömer, "We had many activities with my teachers and friends in high school. Especially in the last year of high school, we became like siblings. I have never had such friendships again in my life", Doğa, "We had good friendships in high school and we never lose touch. We had played many games in the first and second grades", Ŭgur, "I had the best friendships in high school. I never wanted to separate from them in university."

As the students remarked, since the educational system is based on exams and grades, students get happy when they have higher grades and they get unhappy when they cannot. In secondary school, what makes the students happy the most is the quality of social relationship. It is also a requirement of social emotional development of this age period. Students who have been successful in primary school and who loses the attention and affection in secondary school have low remarks and their success decreases. Also, students who define themselves as successful student state that they have few unhappy memories.

\section{b) School Experiences-situations that Make Students Unhappy}

School experiences-situations that have made student teachers who studies in Faculty of Education unhappy throughout their educational lives are;

(a) Exams $(\mathrm{n}=150)$

(b) Homework and other projects $(n=120)$

(c) Wrong university choice $(\mathrm{n}=100)$

(d) Indifference $(\mathrm{n}=70)$

(e) Courses, syllabi and teachers $(n=60)$

(f) Scolding and Insult $(\mathrm{n}=55)$

(g) Pressure- Violence- Punishment $(n=50)$

Direct opinions of the participants related to these factors are given below.

\section{a) Exams}

Ayşe, "Those big exams (YGS, LYS, KPSS) and their results always made me unhappy. I got unhappy especially when the teacher asked our scores in the classroom", Hatice, "Exams of the courses have always made me anxious", Kağan "I felt anxious when all I thought about was exams and scores", Özge "I got unhappy when I got low scores", Mert, "I got unhappy in exam weeks", Mehmet, "I was unhappy when I got low scores", Leyla, "My mathematics results were always low however hard I study", Mert, "I got 54 in mathematics in university and I failed." Deniz, "In secondary school, my teacher got angry when I had failed in mathematics, I suppose she had high expectations of me."

b) Homework and Other Projects
Asl1, "I prepared the homework for English. I submitted it one day late from the deadline and the teacher did not accept it and threw it to the trash", Irem, "I could not participated to lessons in which I do not prepare homework, therefore I got low scores", Mehmet, "Unnecessary homework...", Ziya, "We were not allowed to use eraser when writing essays and the teacher assigned homework all the time. They bored me. The teacher made fun of me when I gave wrong answer to a world knowledge question. My secondary school science teacher always humiliated me during the lessons and yelled at me when I was late. I received notice from deputy principal all the time", Aybuke "I changed my school in 7th and 8th grades and separated from my friends. I could not adapt to the school and my success decreased. I had problems in the last year of high school because of a friend of mine and I cannot say that I am happy with people in university as well."

c) Wrong University Choice

Hasan, "I was not informed about university choice therefore I could not make my choice wisely. I could not study what I wanted. I could not choose English field and that made my unhappy.", Onur, "After secondary school, I was about to register super high school. When my father and I went to the school to get my transcript, deputy principal told my father that his child was useless and that he should sign him to a vocational high school. My father decided to sign me to a vocational high school saying that an educator knew the best.", Meryem, "I wanted to study in a health high school but I couldn't since there is none in Duzce."

\section{d) Indifference}

Zeynep, "In primary school, our teacher only cared about the students who have higher income, she did not care about the rest.", Oya, "I got unhappy when teacher got upset due to the mistakes of some students and she taught reluctantly", Ŭur, "I was sent to kindergarten in order to adapt to school easily. However, I did not like school at all. I wanted to run away all the time. The reason is that our teacher chose to scold us instead of to care about us", Doğa, "I stayed in dormitory when I was in high school and I was deprived of family affection and care."

e) Courses, Syllabi and Teachers

Ozgür, "Block courses and English lessons were boring", Akın, "Mathematics lesson, exam schedules and morning ceremonies were really boring", Alp, "Waking up early in the morning and getting low scores were making me unhappy", Kağan, "Strict rules of the school, bad exam results, being separated from the family", Aliye, "Educational system was based on memorization and I was studying the subjects only to pass them. I did not learn anything at all from some subjects in university. Some teachers did not want to 
teach, all they wanted was ego satisfaction", Ahu, "I have very few happy memories, it was a boring place."

f) Scolding and Insult

Asl1, "We went outside of the school to have dinner. When we were back the principal scolded and insulted us", Merve, "I wanted to study in Faculty of Fine Arts, I asked my painting teacher about it and she reacted harshly. I was embarrassed and upset", Ziya, "In the second year of university, our teacher humiliated us for our clothing and beard. He used many insulting expressions", Mehmet, "Teachers were very strict, they were yelling in the corridors. They thought that the grade is the most important thing", Öznur, "Psychological pressure that university teachers make in their lessons makes me feel anxious”, Buğra, "University education is not what I have expected. Some teachers are oppressive and inconsidered", Derya, "I hated my secondary school teachers. They did not treat fairly to everyone. And I was unsuccessful. They judged me for something I did not do. I cursed them."

g) Pressure- Violence- Punishment

Ali, "öğretmenimizin bize karşı baskı ve şiddet uygulaması bende nefrete neden oluyordu. Anlayıssız, tepeden bakan, saygısı ögretmenlerimizi hiç sevmedim. The fact that teachers applied pressure and violence on us made me hate them. I do not like inconsidered, big-headed, disrespectful teachers", Mehmet, "Hocalardan şiddet gördügü̈m dönemlerI was exposed to violence by teachers", Mualla, "Hocalarm kaprisli, çocuk gibi davranışları yüzünden bizi cezalandırmaları, açma sapan ödevlerin verilmesi Teachers were acting like a child and they punished us all the time. They assigned meaningless homework", Ezgi, "Birinci sinıftaydım. Bazı arkadaşlarımız çok yaramazlık yapmıştı. Öğretmen hepimizi sıra dayağına çekmiști. Başkasının suçu yüzünden ellerime vurulması çok zoruma gitmiş ve çok ağlamıştım I was in the first grade. Some of our friends were very naughty. We ran the gauntlet as a whole class. I felt offended for getting hit in the hand for someone else's fault. I cried a lot", Muazzez, "In primary school, the teacher was checking the homework. If someone had not done their homework, she hit them. My friend told me that I had done the wrong part, I erased that part but then I figured that it was the right one. The teacher hit my hand with a stick. It was her first and last hit but I still feel that fear even today. ", Dilek, "The teacher slapped me in front of the classroom in the first grade", Ŭgur, "The teacher hit us for another student's fault. I was very happy to study in university but I could not find what I had expected. I could not participate in some school activities in secondary school and it made me unhappy", Ŏguz "I changed my school in secondary school and I had to go to regular high school because of the bad friends I had there. They hindered my study. 3 students in the classroom used to hit me and insulted me all the time. I cried in front of teacher because of them."

The participant students state that university students get unhappy when they encounter with attitudes and behaviors that are opposite to their personalities such as interests, values and respect.

\section{Situations that Should be Increased and Provided More in Schools in Order to Make Students Happy}

During the interviews, students were asked to list the situations that need to be provided more in schools. It was aimed to determine the activities that students are deprived of. Students' answers were collected under the items below:

- $\quad$ Student-based schools $(\mathrm{n}=97)$

- Flexible program and principles $(\mathrm{n}=85)$

- Fair and equalitarian teachers $(\mathrm{n}=83)$

- Intramural sportive and cultural activities; extrascholastic trips, observations, social activities $(\mathrm{n}=70)$

- The number of exams should be decreased and education should not be exam-based $(\mathrm{n}=78$ )

- Sufficient and complete school buildings and equipment $(\mathrm{n}=64)$

- Sufficient number of teachers/branch teachers $(\mathrm{n}=57)$

- School and classroom environment that is free from violence, pressure and that praises affection and respect. $(\mathrm{n}=50)$

Direct opinions of the participants related to these factors are given below.

Ayşe, "Exams should be removed", Ömer, "School hours should be adjusted for students, tasks should not be compulsory, students should not be given the lessons they do not like, teachers should be more polite and fair, inequity should not be allowed", Kibar, "Teachers should be well-behaved for a successful school. Students should have good friendship with one another", Mert, "Schools should allow students to express their ideas and thoughts freely, students should also be able to receive feedback. They should be able to speak without hesitation. Their readiness levels, interests and needs should be considered. Teachers should accept that each student is different. Activities should be based on 'learning by doing' and fun activities should be provided", Ahmet, "We need to accept that lessons are not everything. Trips to outside of the school should be arranged and suitable environment for friendship should be created", Mehmet "The number of exams that a student attends throughout his/her education should be decreased. Teachers should treat fairly to each student 
from primary school to university", Oğuz, "Social activities should have been given more importance. School life is not all about lessons, exams and homework", Aynur "School syllabi are very bad. How can you have 4 hours of mathematics in a single day?", Ozan, "Games, activities, sportive activities should have been provided more. Students should attend the courses but these social activities foster learning. They would make me happier", Yllmaz, "Schools are mainly based on exams and grades. I believe that having the affection of students is more important than exams", Ali "If there weren't any exams or homework, I would certainly have been happier. The number and intensity of lessons should have been less, because you feel the need to study even when you are playing. The more social activities a school provides, the happier will be the students. School buildings and equipment should be suitable for learning", Okan "Schools should be free from violence and pressure. Affection and respect should be valued. Management understanding should be based on humanist and international norms.", Zeki, "The number of teachers and branch teachers should be complete", Özgür, "Since I am a sports person, I would rather have a school that contains a sports hall. I did not have that chance since university. Also I was very anxious about the exams."

\section{Results}

The aim of the present research is to determine the educational situations that make student teachers happy and unhappy throughout their educational lives starting from kindergarten to university. The participants were also asked to remark the situations that need to be provided more in schools. The following results were obtained.

School experiences-situations that make students happy throughout their educational lives are participation to classroom and school activities, participation to the lesson, appreciation, rewarding, success and social relationships. On the other hand, school experiences-situations that make students unhappy throughout their educational lives are exams, homework and other projects, wrong university choice, indifference, courses and syllabi, teachers, scolding, insult, pressure, violence and punishment.

According to the students, educational situations that should be provided more in schools are student-based school operations, flexible program and principles, fair and equalitarian teachers, intramural sportive and cultural activities; extrascholastic trips, observations, social activities. Participant students also stated that the number of exams should be decreased, that education should not be exam-based. They remarked that schools should have sufficient equipment, the buildings should be durable and the number of teachers and branch teachers should be complete. Another point of the students is that school and classroom environment should be free from pressure and violence and should give importance to affection and respect.

Social psychologists ask various questions when examining the reasons of particular behaviors. The questions may include the conditions that cause some reactions to occur, situations that create some kind of behavior, the extent of individual behavior to endure ambient factors, situational variations and environmental processes. They emphasize that environmental factors are important in determining the behaviors (Zimbardo, 2017). In contingency approach from management approaches, organizations shape from environmental conditions in which they operate (Tuz, 2004; Genc, 2004). School, as a social interaction system, is a system in which interacting individuals organize in an organic relationship and interconnect one another as a whole (Hoy and Miskel, 2012). School environments and environmental processes are open social systems and they can have a direct impact on students' emotions and behaviors. Research results demonstrate that there is a direct relationship between individuals' happiness and their choices and behaviors in life. Therefore, students who are happy in their life conditions and environments and who experience positive emotions are happier and accordingly more successful. If the factors that the students remarked in the research are fulfilled and situations that make students unhappy are abolished, students can be happier and more successful during their educational lives.

\section{REFERENCES}

[1] Açıkalın, A. (2000). İnsan kaynağının yönetimi geliştirilmesi. Ankara: Pegem Akademi.

[2] Akyüz, Y. (1993). Türk Eğitim Tarihi. Kültür Koleji Yayınlar1. İstanbul.

[3] Apple, M. W. (2017). Eğitim toplumu değiştirebilir mi? (Çeviri Editörü. Şakir Çınkır). Ankara. Anı Yayıncılık.

[4] Aydın, A. (2016). Mutluluk. Ankara. Pegem Akademi.

[5] Cooper, R. K., Sawaf, A. (2010). Liderlikte duygusal zeka. İstanbul: Sistem Yayıncılik.

[6] Çakıroğlu, A. (2007). Relatıonshıp between Qualıty Of Lıfe And Happıness In Turkey. Yayınlanmamış Yüksek Lisans Tezi. Ankara: Ortadoğu Teknik Üniversitesi SBE.

[7] Çepni, S. (2012). Araştırma ve proje çalıșmalarına giriş. Geliştirilmiş 6. Baskı, Trabzon: Celepler Matbaacılık.

[8] Duman, S. (2014). Öğretmen Adaylarında Özgünlük Ve Öz-Duyarlığın Mutluluk İle İlişkisinin İncelenmesi. Yayınlanmamış Yüksek Lisans Tezi. Trabzon: Karadeniz Teknik Üniversitesi EBE.

[9] Duran, A. (2016). Okul Yöneticilerinin Mutluluk Düzeylerinin Öz-Yeterlikleriyle İlişkisi (Amasya İli Örneği) . 
Yayınlanmamıș Yüksek Lisans Tezi. İstanbul: Gaziosmanpaşa Üniversitesi EBE.

[10] Ekiz, D. (2013). Bilimsel araştırma yöntemleri, Ankara: Anı Yayıncilik,

[11] Genç, N. (2004). Yönetim ve Organizasyon Çağdaş Sistemler ve Yaklaşımlar. Ankara:

[12] Glickman, C. D., Gordon, S.P., Gordon, J. M. R. (2014). Denetim ve Öğretimsel Liderlik, Gelişimsel Bir Yaklaşım. . (Çeviri Editörleri: Mualla Bilgin Aksu, Esmahan Ağaoğlu) Ankara, Anı Yayınları.

[13] Gündüz, B. (2012). Öğrenci kişilik hizmetleri ve rehberlik. Ankara: Maya Akademi.

[14] Hoy, W. K. Ve Miskel. C. G. (2012). Eğitim Yönetimi. (Çeviri Editörü: Selahattin Turan). Ankara: Nobel Yayıncılık, 7. Baskıdan Çeviri.

[15] Kara, M. M. (2010). The Relation of Job Satisfaction with Happıness and Success Level. Yayınlanmamış Yüksek Lisans Tezi. İstanbul: Marmara Üniversitesi SBE.

[16] Karasar, N. (2011). Bilimsel araştırma yöntemi-kavramlar, ilkeler, teknikler. 22. Baskı Ankara: Nobel Yayınevi.

[17] Lunenburg, F. C. ve Ornstein, A, C (2013). Eğitim Yönetimi. (Çeviri Editörü: Gökhan Arastaman). Ankara: Nobel Yayıncılık, 6. Baskıdan Çeviri.

[18] Numan, W. L. (2014). Toplumsal Araştırma Yöntemleri (Çeviren Sedef Özge). Ankara, Yayın Odası.

[19] Robbins, P. Stephen. (1994).Örgütsel Davranışın Temelleri. (Çev: Sevgi Ayşe Öztürk), Eskişehir: Etam A.Ş. Basım Ve Yayım,

[20] Sarıcı, M. (2016). Aile İçi Mutluluk İle Ortaokul Öğrencilerinin TEOG Sınavı Başarısı Arasındaki İlişki. Yayınlanmamış Yüksek Lisans Tezi. İstanbul: Nişantaşı
Üniversitesi SBE.

[21] Sahin, Y. (2015). Üniversite Öğrencilerinin Mutluluk, İyimserlik $\mathrm{Ve}$ Özgecilik Düzeylerinin İncelenmesi. Yayınlanmamış Yüksek Lisans Tezi. İstanbul: Gaziosmanpaşa Üniversitesi EBE.

[22] Şentürk, E. (2011). Mutluluk Düzeyinin Sosyo-Demografik Özelliklerle Lojistik Regresyon Analizi Aracılı̆̆ıyla İncelenmesi Ve Türkiye İçin Bir Uygulama. Yayınlanmamış Yüksek Lisans Tezi. İstanbul: Marmara Üniversitesi SBE.

[23] Tüz, V. Melek (2004). Değișim ve Kaos Ortamında İșletme Davranışı, Uludağ Üniversitesi İktisadi ve İdari Bilimler Fakültesi.

[24] Yalçın, R. Ü (2016). Üniversite Öğrencilerinin Saldırganlık Ve Mutluluk Düzeyleri Arasındaki İlişkinin İncelenmesi. Yayınlanmamış Yüksek Lisans Tezi. Erzurum: Atatürk Üniversitesi EBE.

[25] Yazıcı. Ö. F. (2015). Beden Eğitimi Öğretmeni Adaylarının Mutluluk Ve Zindelik Düzeylerinin İncelenmesi. Yayınlanmamış Yüksek Lisans Tezi. Trabzon: Karadeniz Teknik Üniversitesi EBE.

[26] Yıldırım, A. ve Şimşek, H. (2005). Sosyal bilimlerde nitel araştırma yöntemleri, (5. bs.), Ankara: Seçkin.

[27] Yıldırım, A. ve Şimşek, H. (2008). Sosyal bilimlerde nitel araştırma yöntemleri, (6. bs.), Ankara: Seçkin Yayınları.

[28] Yılmaz, G. K. (2015). Durum çalışması, (ed.) m. metin eğitimde bilimsel araştırma yöntemleri. (s.261-285), Ankara, Pegem A Akademi.

[29] Yin, R. K. (2003). Case study research: design and methods ( $3^{\text {rd }}$ ed.). Thousand Oaks, CA: Sage.

[30] Zimbardo, P. (2017). Şeytan Etkisi. (Çeviri: Canan Coikun). İstanbul: Say Yayınları, 2. Baskıdan Çeviri. 